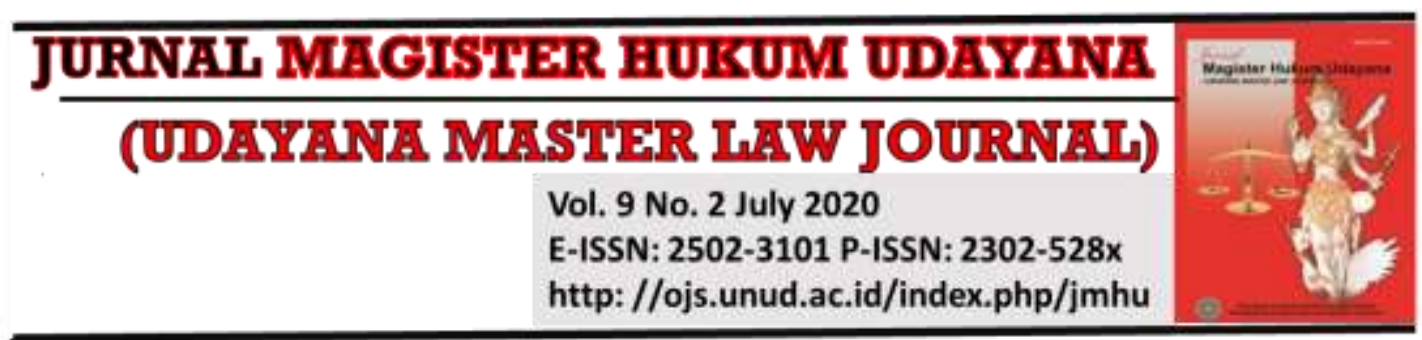

\title{
Pancasila and Religious Values in Establishment of Legal Regulations
}

\author{
Muhammad Hoiru Nail ${ }^{1}$, Made Arya Utama ${ }^{2}$
}

${ }^{1}$ Faculty of Law, Jember University, Email: hoirunail88@gmail.com

${ }^{2}$ Faculty of Law, Udayana University, Email: arya_utama@unud.ac.id

\begin{tabular}{l}
\hline Info Article \\
\hline Received: $2^{\text {rd }}$ April 2020 \\
Accepted: $10^{\text {th }}$ July 2020 \\
Published: $31^{\text {st }}$ July 2020 \\
Keywords: \\
Religious, Values; Legislation; \\
Legal \\
Corresponding Author: \\
Muhammad Hoiru Nail. Emial: \\
hoirunails8@gmail.com \\
DOI: \\
10.24843/JMHU.2020.v09.i02. \\
p.06
\end{tabular}

\begin{abstract}
In the news today (news update), Indonesia was briefly chopped off with headlines from the religion of the great enemy Pancasila. In this paper, we will discuss the relationship between Pancasila, religion and the formation of legislation. This is deliberately discussed in this paper to avoid greater mistakes especially for Indonesian people related to the relationship of religious values and Pancasila, as well as the relationship of religious values with the Formation of Laws and Regulations. This research is qualified into normative legal research that starts from the obscurity of the norms, namely Article 2 the Formation of Laws and Regulations that stated "Pancasila, the source of all sources of state law". The results of this study indicate that religion and Pancasila are not contradicting. Pancasila is formed on the basis of noble values and virtues that exist in each religion which later becomes the first precepts of Pancasila "The Godhead of the One". The relationship of religious values with the formation of legislation is very thick when juridically the religion animates the opening of paragraph 3 of the 1945 Constitution of the Republic of Indonesia and several existing legal products are reflected/based on religion.
\end{abstract}

\section{Introduction}

Pancasila has been indisputable since its birth and has been established as the basis of the state (Philosophiche Gronslaag) and includes also included the precepts outlined in paragraph IV of the 1945 Constitution of the Republic of Indonesia is still very interesting and widely discussed. This is very common considering the existence or position of Pancasila itself by the state has been determined as the source of all sources of state law and Pancasila as the basis of the state.

Pancasila as the basic norm itself is expressly and stated in Article 2 of Law Number 12 of 2011 concerning the Formation of Laws and Regulations, that stated "Pancasila is the source of all sources of state law". Whereas Pancasila as a state basis is expressly and stated in MPR Decree No. XVIII/MPR/1998 concerning the Revocation of the Decree of the People's Consultative Assembly of the Republic of Indonesia Number II/MPR/1978 concerning Guidelines, Appreciation and Practicing of the Pancasila (Ekaprasetia Pancakarsa) and stipulations on the affirmation of the Pancasila of the People's Consultative Assembly of the Republic of Indonesia Number II / MPR / 1978 
as the State Base. In the article 1 is stated that Pancasila as referred to in the Preamble of the 1945 Constitution is the State Base of the Unitary State of the Republic of Indonesia.

Pancasila as the basis of the state for the first time was prepared by the founder of the Indonesian nation on Indonesia independence preparedness. This happened when the BPUPKI session (the Indonesian independence preparatory effort investigating body), the Chairperson of the session Radjiman Wedyodiningrat for the first time when opening the session which lasted from 29 May to 1 June 1945 asked members and figures who wanted to give ideas on the basis of the state. Sukarno, who at the time was a member of the meeting and wanted to offer his ideas, expressed in Dutch "philosofische grondslag". Philosofische grondslag is what is fundamental, philosophy, the deepest thoughts, the soul of deep desires. ${ }^{1}$

Mahfud MD is stated, from the base law perspective the background of the basic consequences arising from the Pancasila as the basis of the country can be seen from at least 3 (three) aspects, namely political, philosophical and juridical (law and legislation). From the political aspect, Pancasila can be seen as a mode of vivendi or sublime agreement that unites all primordial ties into one nation and the whole of Indonesia's vast and plural spilled blood, in the principle of unity. From a philosophical aspect, Pancasila is the basis of beliefs about the idealized society and the basis for the implementation of a nationalized state of values that have grown and developed and are rooted far from the lives of Indonesia's ancestors or ancestors. ${ }^{2}$

Referring to Article 1 Paragraph (3) of the 1945 Constitution of the Republic of Indonesia, the state of Indonesia is a rule of law, so steps are needed to establish or ensure Pancasila as the basis of the state can be carried out or realized. Pancasila as the basis of the state must be realized including the recognition and implementation of guarantees of human rights, limitation of power, respect and enforce the law that is lawfully enforced by the state and others. ${ }^{3}$

These days, there has been a lot of news coverage and there has been a lot of talks everywhere when there is a statement from the head of BPIP (Badan Pembinaan Ideologi Pancasila) Yudian Wayhudi that the great enemy of Pancasila is Religion.4 However, the researcher will not further discuss the statement because according to the author it may be exaggerated by the media or interpret the statement as fragmented (not a complete set of all statements made) and several other meanings that could have to mean what is developing now is not in accordance with what is actually stated by the head of the BPIP. But what is interesting to discuss further is the existence of the Pancasila and the religion, how close the relationship between the Pancasila and the

1 Bahar, S., \& Hudawati, N. (2019). Risalah Sidang Badan Penyelidik Usaha-Usaha Persiapan Kemerdekaan Indonesia (BPUPKI). Jakarta: Sekretariat Negara Republik Indonesia. p. 84

2 Basarah, A., \& Soekarno. (2017). Bung Karno Islam dan Pancasila. Jakarta: Konstitusi Press. p. 78-79

3 Riyanto, A. (2007). Pancasila Dasar Negara Indonesia. Jurnal Hukum dan Pembangunan, 37 (3), 457-493.

4 Gunawan, D. (2020). Blak-blakan Prof Yudian Wahyudi, Kepala BPIP Sebut Agama Jadi Musuh Terbesar Pancasila. https://news.detik.com/berita/d-4895595/kepala-bpip-sebut-agama-jadimusuh-terbesar-pancasila?_ga=2.34560033.1294027023.1595220607-418798054.1580101157. 
religious values and how both of them are and how the position of Pancasila and religion is in the Unitary State of the Republic of Indonesia.

The formation of legislation which is to be made and implemented in Indonesia is also inseparable from the nuances of the Pancasila through the principles of Pancasila. This is the consequence of Pancasila as the basis of the state and the implementation of Article 2 the Formation of the Law and Legislation. The discourse regarding the Formation of Laws and Regulations must consider the values of the Pancasila so the discussion related to religion cannot be separated because one of its principles (the Almighty God) is a manifestation in terms of religion.

The implementation of Pancasila as the basis of the state is a necessity because its already stated in the Indonesian Constitution, that the Pancasila as a basic norm is the absolute standing point when there is an assumption that religion is the great enemy of Pancasila. Based on this, the authors are interested in discussing further and more comprehensively related to the position of both (Pancasila and religion) in the frame of the Unitary Republic of Indonesia.

Religion cannot be separated from the formation of statutory regulations in certain matters. Therefore this research will comprehensively discuss the relationship between Pancasila, religion, and the formation of legislation. The problem to be discussed in this research is first, how is the relationship between Pancasila and religious values within the framework of the Unitary Republic of Indonesia. Second, how is the relationship between religion and the formation of legislation?.

\section{Research Method}

This research is using normative legal research, is based on Article 2 the Formation of Laws and Regulations, and the affirmation of the existence or relationship between Pancasila, Religion, and Legislation. The discovery of a vague of norms related to the existence of Pancasila as the source of all sources of state law related to its preparation which must be based on Pancasila values. The legal sources used in this study came from library research and all legal products (legislation) in force in Indonesia.

\section{Results and Discussion}

\subsection{Pancasila and Religion (religious religious values) are an inseparable unity.}

The discussion on Pancasila and religion will start from the process of preparing the Pancasila itself, which is the real fact, the historical fact of the State which is the main pillar that both are an inseparable unity. The history of Indonesian constitutionality states that all the figures who got the opportunity to convey ideas related to the country's foundation were asked by the chairman of BPUPKI, Mr. Radjiman Wedyodiningrat, all of whom were inseparable from religious ideas, including the figures who were devout religious figures. The historical approach to governance in the basic ideas of the state by a number of Indonesian figures during the BPUPKI session was the initial key to getting answers regarding the relationship between religion and Pancasila. 
The following discussion will be explained one by one as evidence that Pancasila and religion are not contradicting to each other or that Pancasila and religion are an inseparable unity. However, before moving on to the discussion the researcher will emphasize at the beginning of this paper to avoid unilateral claims related to the concepts/ideas of whose figures are used which then become the basis of the state (Pancasila). The formulation of Pancasila is final, it does not need to be debated again, from the legal science perspective it is stated by Presidential Decree (Keppres) RI Number 24 of 2016 concerning Pancasila Birthday. ${ }^{5}$

First, on May 29, 1945 the National Figure who got the first part to convey the idea of the Foundation of the State was Moh. Yamin. On the occasion, Moh. Yamin offered ideas based on his country as follows: ${ }^{6}$

1. The Almighty God

2. Nationality of Indonesian Unity

3. A fair and civilized sense of humanity

4. The people who are led by Wisdom wisdom in deliberative representation

5. Social justice for all Indonesian people.

The Basis of State asked by the chairman of BPUPKI at that time had not been completely answered by the ideas conveyed by Moh. Yamin, in the category put forward by Moh. Yamin not all of the principles were included as the State Basis. In its categorization "deliberation", "representation," and "wisdom (rationalism)" are referred to as the basis (the third basis). Meanwhile other ideas about "nationality", "humanity" and "welfare" are referred to as principles. On the other hand, "representative" is classified as "understanding", while "divinity" is not clear he classifies.7

After further library research, several libraries stated that what was conveyed or offered by Moh. Yamin regarding the basic ideas of the country was done verbally. A few of them stated, that the ideas were later included in his book entitled "preparation of the constitution 1945 "which was formed in 1959 according to M. Hatta as the historical actor immediately denied or stated that Moh. Yamin had never expressed such an idea on May 29, 1945.8 One thing that needs to be stressed is that Moh Yamin in any literature has never named the concept of the basic ideas the country has to offer.

Apart from the existing controversy and denied by some historical figures or actors, the most important thing in this study what the researcher wants to convey here is that the figure (Moh.Yamin) also agreed and did not debate the existence of the basic ideas of the state with Pancasila. Moh Yamin (apart from the controversy of the basic ideas of

5 Based on the formal legality, it is hoped taht there will be no more discourse about when the Pancasila was born and by whon the idea of pancasila was stated. In the predential decree explicitly that Pancasila was born on the basic idea of the state which was delivered on june 1, 1945 by Soekarno.

6 Bahar, S., \& Hudawati, N. (2019). Loc.Cit. p. 12

7 Latif, Y., \& Paripurna, N. (2012) Historitas, Rasionalitas, dan Aktualitas Pancasila. Jakarta: PT. Gramedia

8 Kusumah, A. B. (2004). Lahirnya Undang-Undang Dasar 1945: Memuat Salinan Dokumen Otentik Badan Oentoek Menyelidik Oesaha2 Persiapan Kemerdekaan. Jakarta: Fakultas Hukum Universitas Indonesia. p. 42. 
the state) he offered was a national figure who contributed greatly to the birth of religious nuances based on the state. That way this shows that the character Moh. Yamin as a historical actor basically (especially in this study) did not make a conflict between religion and the state foundation (Pancasila).

Second, the next figure who got the chance at the BPUPKI session on May 31, 1945, was Ki Bagoes Hadikosoemo. This figure is a figure who comes from Islamic religious circles. Ki Bagoes Hadikoesoemo offers the concept of the basic ideas of the state based on the concept of the Islamic state, the concepts it offers are as follows: ${ }^{9}$

\section{The doctrine of Faith or Belief in God and unseen matters}

According to this teaching, out of faith comes a good character. Man's evil is driven by his evil will, and his evil will come from lust, and to break that thing requires something bigger, that is, a firm faith. Ki Bagoes Hadikoesomo described a parable, if someone is angry, which anger comes from lust. Nothing can block it except with a stronger will than the anger, if you have strong faith, you will overcome your lust.

2. The teachings of worship and worship to God.

Someone who carries out worship will certainly be beneficial to the worship he does if the worship is truly felt and believed. Because the matter of worship is something direct relationship between the human soul and God Almighty. The benefits of worship surely someone who does it will feel it, one of which is by strengthening faith and the heart so that it stands upright and lives eagerly burning in the soul. Faith that is not followed by religious deeds will inevitably be weak and helpless, and eventually will die, both teachings are a human obligation to God to be a guide for spiritual training and education.

\section{The doctrine of Charity Sholeh}

The words "do good" have a very broad meaning, but have a clear meaning. Good deeds are doing good to parents, children, neighbors and guests, and doing good to other groups, and to society as a whole.

4. The teachings of Jihad in the path of Allah.

What is meant by striving in the way of Allah here is to like and be willing to fight earnestly, wholeheartedly, willingly sacrifice property, body and soul and uphold justice and truth?.

Ki Bagoes Hadikoesomoe expressly stated and offered ideas on the basis of the state which would later be used in independent Indonesia based on the Qur'an and AlHadith. This was done because Ki Bagoes Hadikoesomo considered that the foundation of the country was very appropriate to use since the religion of Islam reached 90 percent of the total population of Indonesia, something that was risky when 90 percent of religious adherents were ignored, which resulted in lack of enthusiasm or lack of enthusiasm among Muslims to the state later if the country's basis is not based on the basic concept of the state it offers.

\footnotetext{
9 Bahar, S., \& Hudawati, N. (2019). Loc.Cit. p. 37-38
} 
The basic idea is getting a lot of rejection from several other figures, including Soekarno, M. Hatta and other figures. The figures reminded that the independence movement was carried out by all religions, although in the concept of the basic ideas of the state offered by Ki Bagoes Hadikoesomo gave a guarantee against adherents of other religions other than Islam with the concept of doing good. But other figures disagree with the idea apart from guarantees for minorities.

The author wants to explain here that the basis of the state, Pancasila and religion here is not contradicting, even religion is a contribution made from the basic ideas of the state of some of the figures mentioned above. This shows that once religion is not contradicting, religion becomes a pillar of the foundation of the state. The concept of the basic idea of the state of Ki Bagoes Hadikoesomo cannot be said to be the Pancasila or the basis of a state as an enemy of religion, expressly even the concept of religion is offered by Ki Bagoes Hadikoesomo.

Third, the figure of Soepomo conveys ideas about the state and religion. Several times Soepomo addressed disagreement on the basic concept of the state based on only one religious belief. He further stated that the national state which wanted to be fought for independence (Indonesia) which later would be united from several things did not also indicate that the country that was to be developed was an "a religious" state or a country that did not discard or peddle between state and religion.

Soepomo offered the idea of integralism (a unified national state), a country which would not unite itself with the largest group, but would overcome existing features and become one unit. The state does not choose one strong group but guarantees the life of the nation as an inseparable unity. ${ }^{10}$

One thing the researcher wants to emphasize here is that the issue of religion is not at all an enemy of religion on the basis of the basic concept of the state idea offered by Soepomo. Soepomo repeatedly stated that all religions would be considered by the state, not only concerned with or focused on one particular group, but the state must guarantee the safety of all citizens (regardless of group, adherents of any religion).

Here there is much debate about the concept of religion and the state, but one thing is certain that there was never a basic concept of the state offered by the figures (Moh. Yamin, Ki Bagoes Hadikoesomo, and Soepomo) wanting to exclude or make the state confront the religious state as an enemy. What exists is an offer of basic concepts of the state which are all based on religion (both those in basic ideas of the state that do not want one particular religion to be the basis of the state or who explicitly want the concept of basic ideas of the state based on adherents of a particular religion), but all of them never place the basis of the state is contrary to any religion or religion that is upheld by citizens.

Fourth, or finally the basic concept of the state offered by Sukarno on June 1, 1945. Following the basic concept of the state offered by Sukarno at the BPUPKI session:

1. Indonesian nationality

2. Internationalism

3. Consensus or democracy

4. Social welfare

10 Ibid. p. 32 


\section{Culture of God}

For the first time in the BPUPKI session, the name Pancasila came out of the statement of the basic concept of the state offered by Sukarno. Sukarno gave the name of the country's basic proposal as "Pancasila". Panca means five, while still means base or base. ${ }^{11}$ But what the researcher wants to explain here is the connection with the concept of religion offered by Sukarno.

Soekarno in his basic idea of the state he offered the first phrase used in the basic concept of the country which he offered to use the word "Culture of God". Sukarno wanted to give an understanding that whatever his religion, citizens were free to embrace their religion and beliefs in the country that was to be fought for (the Indonesian state).

Muslims, Christians, Hindu, and other religions are free to carry out the commands of their God. The prophets in each religion teach about respect (verdraagzaamheid) among adherents of other religions, and that is what must be shown and done and used as the basis of the state used by the Indonesian people. Adherents of existing religions live side by side and respect each other in carrying out their respective religious orders. Indonesia is an archipelago state thus it has much diversity such as geographies, culture and religion. That diversity is respected and used as the power to promote unity, because of that according to history the figures uphold the unity based an Almighty God to achieve social justice.

From some of the figures mentioned above, none of them or in some of the debates at the BPUPKI session, there are arguments to position religion as an enemy of Pancasila or vice versa. Everything has agreed or the resultant (based on historical studies), ${ }^{12}$ the basic formulation of the state (Pancasila) is based on existing religious values, so the last choice used as the basis of the state is the phrase "the divinity of the Almighty, indicates that Indonesia is using religion as the basis of its State. It does not mean that Indonesia only based on one religion but Indonesia recognizing, protecting, respecting and giving the same treatment for all religion which are embraced by the citizens.

Based on some basic concepts of several national historical actors that exist and have been discussed, the actual religious values that have been reflected. The religious values that have become one in a noble agreement (vivendi mode) in the form of the first precepts of the Pancasila "Belief in the one and only God". Thus it is not appropriate if there is an assumption that religion is a great enemy of Pancasila or vice versa, there is a religion not an enemy of the Pancasila, Pancasila is a unity of various religious values.

The philosophical foundation of this discussion, the statement from M. Hatta who stated that the first precept "the divinity of the Almighty" became the basis and led the other precepts. For the writer, it can be stated that the second precepts and afterward were imbued with the first precepts of the Pancasila, the second precepts and afterward were inspired and inspired by the first precept of "the One Godhead". Furthermore, that the second, third, fourth and fifth precepts of Pancasila are all

11 Pancasila come from the sangsekerta word which means five rock or five moral prinsiples. In ancient indonesian history, the word of pancasila are found in the book NEGARAKERTAGAMA (a historical record of hindu majapahit kingdom/1296-1478).

12 Bahar, S., \& Hudawati, N. (2019). Loc.Cit. p. 57-58 
imbued with the breath of God/religion. The author also states that with this condition Indonesia is not a religious state and not a secular state but a religious state (a country that protects all religious adherents). The implementation on the basis of the Almighty God becomes the basis for the other precepts in Pancasila, which can be seen from several court decisions by expressly stating that "for the sake of justice based on a Godhead."

\subsection{The Relationship between Religion and the Establishment of Legislation in Indonesia}

It will emerge several general questions related to whether certain religious laws can be the basis in the Formation of Legislation. How the basis for the validity and or binding capacity of the Formulation of Legislation based on religion can be binding on the community, and several other general questions related to religious relations with the formation of legislation.

Discussion of the relationship of religion or the relationship of religious values of religion with Pancasila the author tries to prove legally formal that religion is something that cannot be separated in the Formation of Legislation. The evidence can be clearly seen in the highest law of the Indonesian state, namely the 1945 Constitution of the Republic of Indonesia. In its opening, the religious nuance is very strong which indicates that the formation of the 1945 Constitution of the Republic of Indonesia cannot be separated from religious values or values, such as is stated in the 3rd paragraph preamble: "Thanks to the grace of Allah Almighty and by being encouraged by noble desires, so that a free national life, the Indonesian people hereby declare their independence". The 3rd paragraph of preamble clearly and firmly there is a religious nuance that is presented in the positive law in Indonesia. The phrase provides an explanation and meaning that all forms of struggle that have been carried out to liberate cannot be separated from the existence of the power of God as a manifestation or manifestation of efforts to liberate the Indonesian state.

The makers of basic law are very conscious and convinced that all actions taken are not out of the control of God, therefore as followers of the religion, the reaction to the greatness of God that accompanies all the struggles of all Indonesian people is clearly revealed and reflected in the opening of the 1945 Constitution of the Republic of Indonesia. This shows that there is an inseparable relationship between religion and statutory regulations.

Discourse or analysis to answer general questions about whether certain religious laws can be used as a basis for the formation of legislation. Of course, to answer that we need arguments or juridical evidence to answer that certain religious laws can be used as a basis for the formation of legislation, one example that can be used and will be discussed in this discussion is the basis of Islamic law is the basis for the formation of legislation.

Islamic religious law is the basis for the formation of legislation here, for example with the birth of Law Number 21 of 2008 concerning Sharia Banking, Law Number 8 of 2019 concerning the Operation of Hajj and Umrah, and Law Number 23 of 2011 concerning Management of Zakat. All three of these laws were the basis of their formation was 
based on the provisions of Islamic law. The following is concrete evidence that the basis for the formation of the Law is based on Islamic values:

1. Sharia Banking in conducting its business activities based on sharia principles, economic democracy, and the principle of prudence (article 2 of Law Number 21 Year 2008 concerning Sharia Banking).

2. Hajj is the fifth pillar of Islam for Muslims who are able to carry out a certain series of worship in Baitullah, community, and certain places, times, and conditions. (Article 1 Paragraph 1 of Law Number 8 of 2011 concerning the implementation of Hajj and Umrah)

3. Zakat is a compulsory asset issued by a Muslim or business entity to be given to those entitled to receive it in accordance with Islamic law. (Article 1 Paragraph 2 of Law 23 of 2011 concerning Management of Zakat).

On the other hand, each section of the head of the Statutory Law in Indonesia is written: "Based on Ketuhanan Yang Maha Esa".

The above evidence shows that the formation of legislation can be based on certain religious laws, but it requires firm confirmation that the legal characteristics of the law are private enough products, not public law (Criminal Law, Constitutional Law, State Administrative Law). With regard to public law products, it cannot be based solely on the basis of one religion, public law is created and applied to all Indonesian people by taking all good values in all existing religions so that their enforcement is carried out in public.

The foregoing as well as answering the second general question related to the binding status of a legal product based on the basis of religious law only covers or only becomes a legal choice for followers of that religion alone. The law does not have a binding capacity for adherents of other religions, even for adherents of Islam itself, the provisions are optional. This means that the followers of Islam themselves are also not required to register Hajj, conduct activities in Islamic banking, and make zakat payments at designated institutions.

\section{Conclusion}

Referring to the discussion above, the authors conclude several things as follows:

The relationship of religion or the relationship of religious values with Pancasila is inseparable. Pancasila is created on the basis of religious values that exist in Indonesia. Religion is not enemy of Pancasila because the values of goodness that exist in each religion have been mixed into one with the presence of the first precept of "the Godhead of the Almighty", even explicitly the Godhead of the Almighty was made in the middle of a verdict judge "for the sake of Justice based on the Almighty God".

The relationship of religious values with the formation of law and legislation is something that cannot be separated (Pancasila and religious into one unity that can not be separated). Religion and religious values have colored and animates the law the paragraph 3 of preamble the 1945 Constitution of the Republic of Indonesia. Based on these, the close relationship between religious values and Pancasila can be found on the formation of the law and legislation, and also appears in positive law in Indonesia. 


\section{References}

\section{Book}

Bahar, S., \& Hudawati, N. (2019). Risalah Sidang Badan Penyelidik Usaha-Usaha Persiapan Kemerdekaan Indonesia (BPUPKI). Jakarta: Sekretariat Negara Republik Indonesia.

Basarah, A., \& Soekarno. (2017). Bung Karno Islam dan Pancasila. Jakarta: Konstitusi Press.

Kusumah, A. B. (2004). Lahirnya Undang-Undang Dasar 1945: Memuat Salinan Dokumen Otentik Badan Oentoek Menyelidik Oesaha2 Persiapan Kemerdekaan. Jakarta: Fakultas Hukum Universitas Indonesia.

Latif, Y., \& Paripurna, N. (2012) Historitas, Rasionalitas, dan Aktualitas Pancasila. Jakarta: PT. Gramedia Pustaka Utama.

\section{Journal}

Riyanto, A. (2007). Pancasila Dasar Negara Indonesia. Jurnal Hukum dan Pembangunan, 37 (3), 457-493.

\section{Website}

Gunawan, D. (2020). Blak-blakan Prof Yudian Wahyudi, Kepala BPIP Sebut Agama Jadi Musuh Terbesar Pancasila. https://news.detik.com/berita/d-4895595/kepalabpip-sebut-agama-jadi-musuh-terbesarpancasila?_ga=2.34560033.1294027023.1595220607-418798054.1580101157.

\section{Laws and Regulation}

The Constitution of the Republic of Indonesia in 1945

Law number 8 of 2019 concerning the organization of Hajj and Umrah, (Republic of Indonesia State Gazette 2019 number 75, additional Republic of Indonesia State Gazette number 6338).

Law number 15 of 2019 concerning change law number 8 f 2011 concerning the formation of law and regulations, (Republic of Indonesia State Gazette 2019 number 183, additional Republic of Indonesia State Gazette number 6398).

Law number 23 of 2011 concerning Zakat Management, (Republic of Indonesia State Gazette 2011 number 115, additional Republic of Indonesia State Gazette number 5255).

Law number 21 of 2008 concerning Syariah Banking, (Republic of Indonesia State Gazette 2008 number 94, additional Republic of Indonesia State Gazette number 4867).

Predential decree number 24 of 2016 concerning the birthday of Pancasila. 